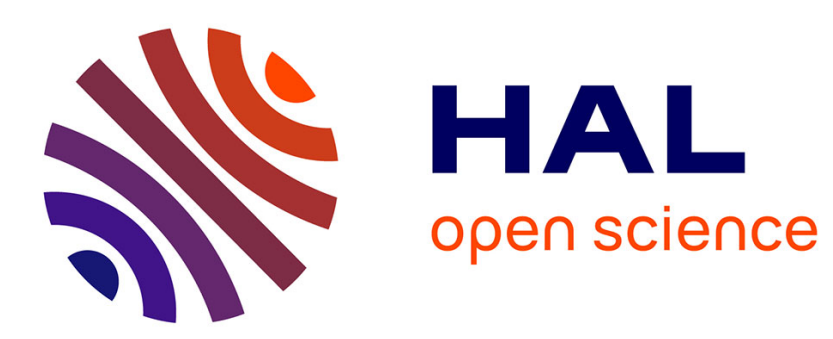

\title{
Plastic nesting behavior of Centris (Centris) flavifrons (Hymenoptera: Apidae: Centridini) in an urban area
}

Celso Martins, Marcella Peixoto, Cândida Aguiar

\section{To cite this version:}

Celso Martins, Marcella Peixoto, Cândida Aguiar. Plastic nesting behavior of Centris (Centris) flavifrons (Hymenoptera: Apidae: Centridini) in an urban area. Apidologie, 2014, 45 (2), pp.156-171. 10.1007/s13592-013-0235-4 . hal-01234712

\section{HAL Id: hal-01234712 \\ https://hal.science/hal-01234712}

Submitted on 27 Nov 2015

HAL is a multi-disciplinary open access archive for the deposit and dissemination of scientific research documents, whether they are published or not. The documents may come from teaching and research institutions in France or abroad, or from public or private research centers.
L'archive ouverte pluridisciplinaire HAL, est destinée au dépôt et à la diffusion de documents scientifiques de niveau recherche, publiés ou non, émanant des établissements d'enseignement et de recherche français ou étrangers, des laboratoires publics ou privés. 


\title{
Plastic nesting behavior of Centris (Centris) flavifrons (Hymenoptera: Apidae: Centridini) in an urban area
}

\author{
Celso F. Martins ${ }^{1}$, Marcella P. Рeixoto ${ }^{2}$, Cândida M. L. Aguiar ${ }^{3}$ \\ ${ }^{1}$ Departamento de Sistemática e Ecologia/CCEN, Universidade Federal da Paraíba, Cidade Universitária, 58051-900, \\ João Pessoa, PB, Brazil \\ ${ }^{2}$ Programa de Pós-Graduação em Ciências Biológicas (Zoologia)/CCEN, Universidade Federal da Paraíba, Cidade \\ Universitária, 58051-900, João Pessoa, PB, Brazil \\ ${ }^{3}$ Departamento de Ciências Biológicas, Universidade Estadual de Feira de Santana, Av. Transnordestina, s/n, 44036-900, \\ Feira de Santana, BA, Brazil
}

Received 25 May 2013 - Revised 23 July 2013 - Accepted 16 August 2013

\begin{abstract}
Centris flavifrons is a ground-nesting solitary bee species that has an important role in crop and native plant species pollination in the Neotropical region. However, the nesting biology and ecology of this species are little understood. We studied the nesting biology of $C$. flavifrons by observing 287 nests in an urban garden. Females built nests only during the dry season from September to March and exhibit notable flexibility in the amount of time each nest is active and the number of brood cells produced as a consequence. Nests were established on horizontal, sunny, sandy surfaces without vegetation. Our nest excavations revealed a main tunnel with lateral branches and an average of five cells per nest (range, 1-12 cells). The duration of a nest from digging to closure was on average 6.9 days (range of 2-19 days, $n=141$ ) with $69 \%$ of nests active for 2-7 days. Mesoplia regalis was observed entering the nests and emerged from the cells of $C$. flavifrons, but the parasitism rate was low. The implications of this flexibility in nest activity duration and brood cell number and the low pressure from parasites are discussed.
\end{abstract}

nesting ecology / ground nesting / solitary bees / oil collecting bees / Mesoplia regalis

\section{INTRODUCTION}

Pollination is an essential ecosystem service. Due to the threat of decline of pollinators, it is important to understand the nesting biology of bee species. Centris flavifrons (Fabricius) is a ground-nesting bee species that serves an important role in the pollination of agricultural crops, such as Passiflora alata and Malpighia emarginata (Gaglianone et al. 2010; Freitas et al. 1999; Vilhena et al. 2012), and of native plant species, including Byrsonima spp., in the

Corresponding author: C.F. Martins, cmartins@dse.ufpb.br

Manuscript editor: Klaus Hartfelder
Neotropical region (Albuquerque and Rêgo 1989; Teixeira and Machado 2000; Bezerra et al. 2009). The importance of pollinators has led to an increase in studies of the nesting biology of native bees, including some Centridini species, known to be pollinators of many tropical crops (Frankie et al. 1989; Freitas et al. 1999; Gaglianone et al. 2010). However, research into the nesting biology (Jesus and Garófalo 2000; Aguiar and Martins 2002; Aguiar and Garófalo 2004; Aguiar et al. 2006; Oliveira and Schlindwein 2009; Pina and Aguiar 2011) and provisioning behavior (QuirozGarcia et al. 2001; Roubik and VillanuevaGutiérrez 2009; Dórea et al. 2010a, b; Rabelo et al. 2012) of bees has been focused on trap-nesting species because their nests are easier to locate and manipulate than those of ground-nesting bees.

The genus Centris contains 150 species mainly of specialist bees that collect floral oils 
to mix with pollen and sometimes nectar to make larval food, or to line their brood cells, presumably to waterproof (Cane et al. 1983; Jesus and Garófalo 2000; Michener 2007). All the species belonging to subgenus $C$. (Centris) construct their nests in the ground. These ground-nesting oil bees make oil-collecting trips in the process of nest construction to line the brood cell wall then pollen-collecting trips to provision the brood cell and then additional oilcollecting trips (Vinson and Frankie 1988; Aguiar and Gaglianone 2003).

Although Centris is one of the most important groups of noncorbiculate bees in the Neotropics (Thiele 2002), there have been only a few studies into the nesting biology of Neotropical, groundnesting Centris species [Centris flavofasciata Friese, Vinson et al. 1987; Centris decolorata Lepeletier as Centris leprieuri (Spinola), Gottsberger et al. 1988; Centris collaris Lepeletier and Centris fuscata Lepeletier, Camillo et al. 1993; Centris dorsata Lepeletier, Laroca et al. 1993; Centris tamarugalis as Centris mixta tamarugalis Toro \& Chiappa, Chiappa and Toro 1994; Centris aenea Lepeletier, Aguiar and Gaglianone 2003; C. flavifrons (Fabricius), Vinson and Frankie 1988; Rêgo et al. 2006]. As a result, nest structure details, such as brood cell depth, is known for only $14.6 \%$ of Centris species (see review in Cane and Neff 2011).

Despite its wide Neotropical distribution, the nesting biology of $C$. flavifrons has been studied in only three remote locations to date. The initial investigation into nest structure and male mating behavior was conducted in the dry forest of Costa Rica, by Vinson and Frankie (1988) and by Vinson et al. (1996, 1997). More recently, Rêgo et al. (2006) described nest building behavior and the plant species used for brood provisions in a savanna area of Northeastern Brazil. In addition, Gonzalez et al. (2007) described two nests in Colombia. But for the current study, by intentionally selecting a large nest aggregation in an urban setting, we were able to observe the nesting biology of $C$. flavifrons to a degree of detail not previously possible. In this paper, we present new findings about the nest architecture and the nest building and brood provisioning behavior of this ecologically important, ground-nesting bee species.

\section{MATERIAL AND METHODS}

\subsection{Study area}

The study area was located in an urban area of João Pessoa city $\left(7^{\circ} 9^{\prime} 11^{\prime \prime}\right.$ S; $34^{\circ} 50^{\prime} 28^{\prime \prime}$ W), Paraiba State, Northeastern Brazil. The climate is hot and humid, tropical (As', accordingly to Köppen classification), with annual average temperatures of $26^{\circ} \mathrm{C}$. The rainy season lasts from March to August, and the average annual rainfall is $1,700 \mathrm{~mm}$ (Lima and Heckendorff 1985). The nest aggregation of $C$. flavifrons was established in a home garden $\left(642.46 \mathrm{~m}^{2}\right.$ total area) planted with fruit trees (M. emarginata, Mangifera indica, Anacardium occidentale, Spondias purpurea, Eugenia uniflora, Syzygium malaccense, Psidium guajava, Citrus lemon, Citrus cinensis, Cocos nucifera, Carica papaya, and Morus sp.) and grass (Figure 1a). The garden had some small areas with bare soil: 22 bare ground circles, approximately $1 \mathrm{~m}$ in diameter, surrounding each of the orchard trees, and a narrow strip of land along the walls of the garden $(20 \mathrm{~cm} \times 167.6 \mathrm{~m})$.

In addition to the bare ground areas, ten cement garden pots $(52 \mathrm{~cm}$ high $\times 52 \mathrm{~cm}$ in diameter) filled with soil were placed in the garden in 2011 to serve as available nest sites (Figure 1a). Six of the pots were buried at ground level and the remaining four placed on the ground surface.

\subsection{Data survey}

Nesting activities of $C$. flavifrons were observed mainly during two breeding seasons: October/2010 to March/2011 and September/2011 to January/2012, with occasional observations done in the 2009 and 2012 nesting seasons. During November in 2010 and 2011, we carefully observed a total of 15 nests. To understand the timing of nest construction and provisioning, each nest was observed continuously from 0430 to 1730 hours every day from first digging by the female through nest closure. For the other observation periods, nests were monitored for $4-5 \mathrm{~h}$ on alternate days. Observed nests were marked with numbered wood or aluminum sticks. 
In the first period of study, 50 females that were initiating nesting were captured and marked on the thorax with different colors combinations made with ink pens (Edding ${ }^{\circledR} 791$ ) and/or individually numbered plastic tags. The markings allow for easy detection and distinction of each individual, even at a moderate distance, without causing injuries or stress due to recapture (Peakall and Schiestl 2004). We recorded the daily activity of each nesting female: duration of time spent inside and outside the nest, provisioning resources brought to the nest, and the behavior of females in the nest area. A total of approximately 161 days and $928 \mathrm{~h}$ of observations were made. As individually marked bees could be observed during the whole day, after some training, we could differentiate the oil- from pollen-collecting trips with a good degree of confidence. On occasion, the pollen loads of some collecting trips presented an oily brightness but clearly contained mostly pollen. Thus, we could count the number and measure the duration of the initial oilcollecting trips for lining the brood cell followed by the number and duration of the pollen-collecting trips for provisioning the cell and then the number and duration of the last oil-collecting trips for provisioning and closing the cell. Based on the number and duration of the oilcollecting trips for lining the cell and pollen-collecting trips for provisioning the cell, we calculated the total time invested for lining compared with the total time invested for provisioning each cell with pollen. Mann-Whitney $U$ and $Z$ tests (when in both samples $n>30$ ) were used to compare the median number and duration of oil and pollen-collecting trips and the duration of a nest stay after oil and pollen-collecting trips (BioEstat 2007).

Two active nests in the ground were excavated to observe nest architecture. Six concluded nests, established in the garden pots, were excavated to verify the number of constructed brood cells and obtain immatures; therefore, the isolated nests inside the garden pots made it possible to check the number of cells constructed by each female.

In order to determine the length of time necessary to complete development, sex ratio, and parasitism rate, some intact excavated cells were put in a glass jar measuring $24 \mathrm{~cm}$ high $\times 14 \mathrm{~cm}$ diameter filled to one third of capacity with soil from the excavation site (in 2012, the sandy soil was sterilized for $5 \mathrm{~min}$ in a microwave). All the brood cells from the small garden pot, and some other cells that were broken during excavation, were opened and examined upon excavation; the other retrieved brood cells were put in the glass jar to await emergence, while others were opened periodically over time to assess the developmental stage of the offspring. In addition, 20 cages $(70 \times 70 \mathrm{~cm}, n=10 ; 15 \times 15 \mathrm{~cm}, n=10)$ of aluminum with nylon screens were placed over concluded nests to capture emerging imagoes.

To evaluate the dispersion of nests inside the aggregation, we divided the area in $1-\mathrm{m}^{2}$ quadrates and counted the number of nests per quadrate. The index of dispersion ( $I=$ variance/mean ratio) and chi square to test its significance was calculated according to Elliott (1977).

\section{RESULTS}

\subsection{Nesting sites and nest density}

We observed 174 C. flavifrons nests in the first breeding season and 113 nests in the second breeding season. Nests were established primarily in flat, sandy soil without vegetation, but occasionally, some females constructed nests in areas with a little grass cover. As a result, nest distribution was mostly densely aggregated in areas of bare soil without vegetation. C. flavifrons females nested in 10 of the 22 circles surrounding orchard trees and much of the narrow $(20 \mathrm{~cm})$ strip of bare ground along the walls of the garden, although some isolated nests were established in the lawn area.

Nests were not homogeneously distributed throughout the garden site: there were areas with a higher concentration of nests in particular ground circles around trees and specific areas close to the garden walls suggesting a "preference" for bare soil. The distribution of the number of nests per quadrate from the entire breeding season of 2010 showed that nests presented aggregated dispersion (index of dispersion $I=4.666$, chi square $=2,725.329$, $P<0.001, n=585$; Figure 2a). Considering only the bare areas of the garden, the densities of nests in the entire first and second breeding season were 1.7 nests $/ \mathrm{m}^{2}$ and 1.1 nests $/ \mathrm{m}^{2}$, respectively. Other than the lack of vegetation, there were no apparent differences between areas used for nesting compared to other areas that were not used.

Five of the ten soil-filled garden pots were utilized as nesting sites by $C$. flavifrons. In addition, one female built a nest in a smaller garden pot containing a plant (Figure 1d). 


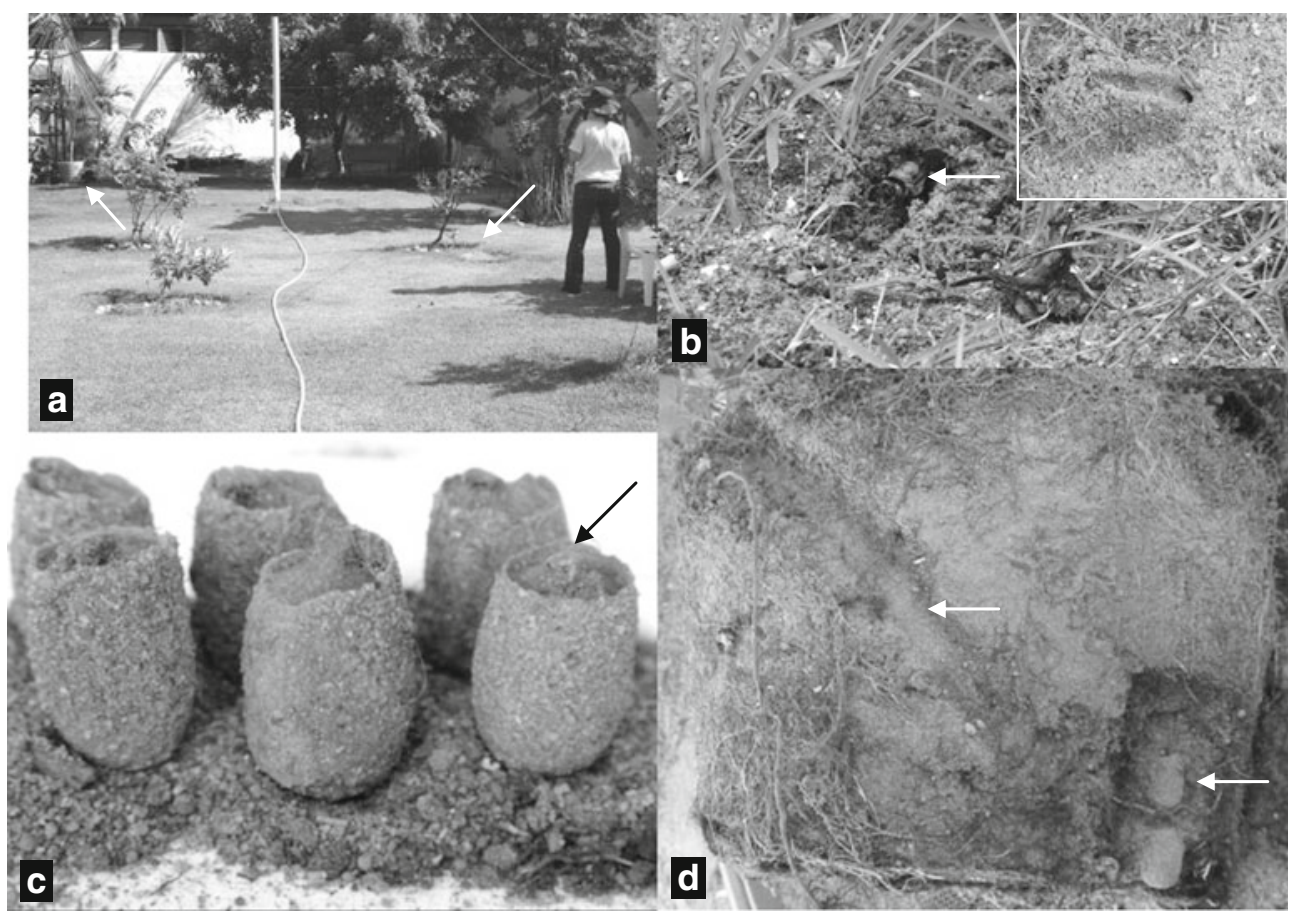

Figure 1. a General view of the nesting area: the observer is monitoring a nesting female in a garden pot buried at ground level that is the same size as the pot in the background (arrows indicate garden pot locations). b Female (arrow) starting to dig a new nest producing the central furrow characteristic of $C$. flavifrons (in detail the typical mound of soil with the median furrow). $\mathbf{c}$ Brood cells of $C$. flavifrons (the arrow indicates the central process over the cell cap). $\mathbf{d}$ Excavation of the small garden pot showing the main tunnel and two aligned brood cells at approximately $40 \mathrm{~cm}$ deep.

\subsection{Nest architecture and natal cell structure}

The shape of the nest entrance was circular and well defined. Entrances were most often exposed but, in some cases, were hidden under leaves, roots, or stones. During the initial digging of the nest tunnel by the female, the entrance was typically subtended by a mound of soil with a median furrow formed by the backward movement of the female as she removed soil from the tunnel entrance (Figure 1b). The entrance led to a downward sloping $\left(\sim 45^{\circ}\right)$ main tunnel, measuring between 13 and $18 \mathrm{~mm}$ in diameter. The excavated nests revealed the main tunnel splitting into lateral branches (10-20 cm long) beginning between $20-30 \mathrm{~cm}$ depth. The lateral branches terminated in one brood cell at $28-60 \mathrm{~cm}$ from the surface, although three cells from a nest constructed in a smaller garden pot $(29 \mathrm{~cm}$ high $\times 34 \mathrm{~cm}$ diameter) were at 10,13 , and $15 \mathrm{~cm}$ depth. The cells were situated vertically, and in one case, in the same smaller garden pot, two cells were arranged in a vertical linear series at the end of the lateral branch (Figure 1d). The number of brood cells varied from 1 to 12 cells per nest $(X=5.7 \pm$ $3.47, n=15$, Table I).

The brood cells of $C$. flavifrons are barrelshaped with a rounded base and a cap, or operculum, sealing the top of the cell. The sides of the cell extend above the cap forming a collar (Figure 1c). The dimensions of the cells $(n=13)$ were $26-30 \mathrm{~mm}$ in length $(X=28.2 \pm 1.06), 13-15 \mathrm{~mm}$ diameter near the collar $(X=14.2 \pm 0.55)$, and $15-23 \mathrm{~mm}$ in diameter in the widest portion $(X=18.3 \pm 2.28)$. The 

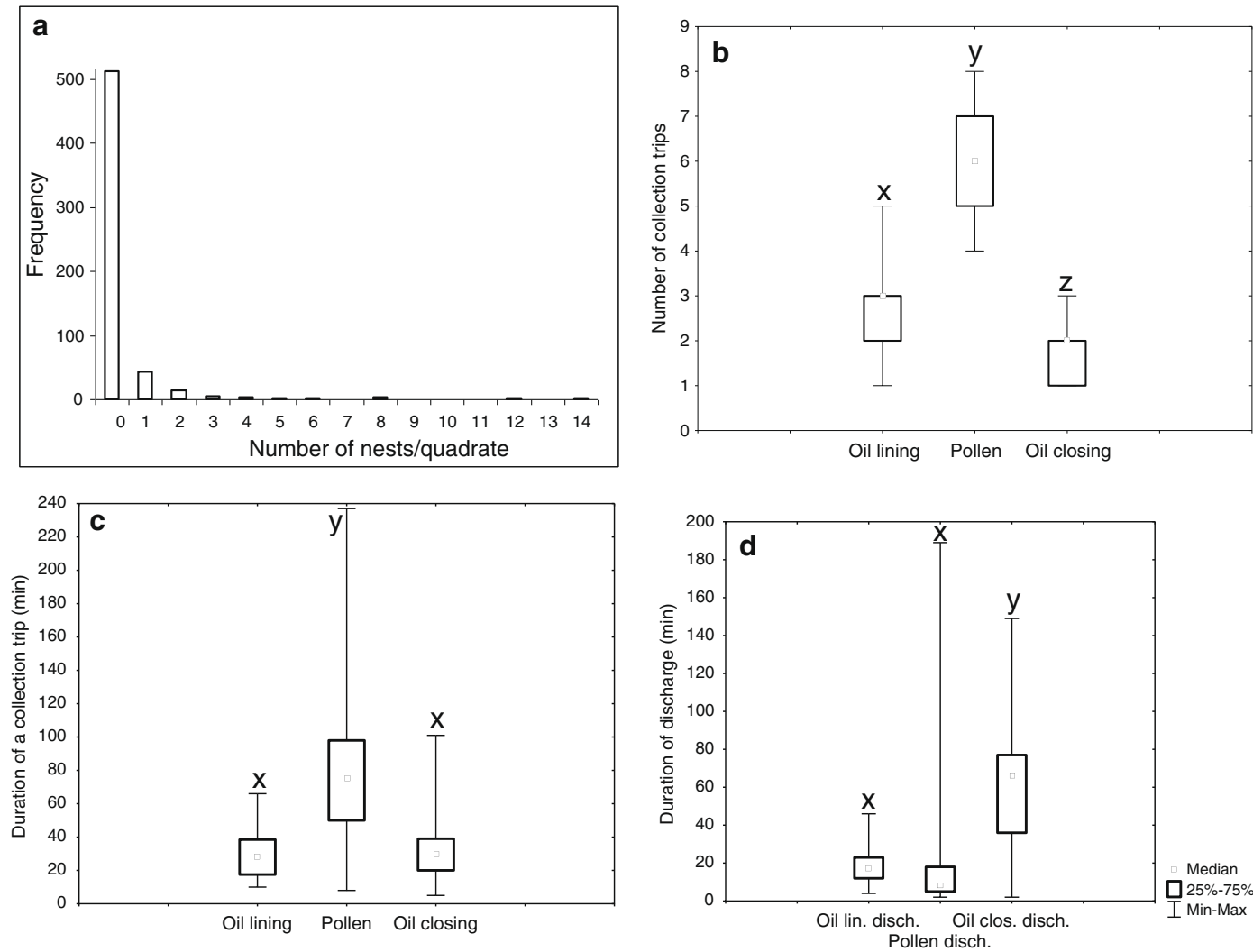

Figure 2. a Frequency distribution of the number of nests per $1-\mathrm{m}^{2}$ quadrates in the entire breeding season of 2010. b Number of collecting trips to complete one cell. c Duration of a collecting trip. $\mathbf{d}$ Duration of discharge of oil or pollen after a collecting trip. (Different letters indicate significant differences $P \leq 0.001$ ).

operculum has a central curved projection forming a terminal nipple, measuring $4-5 \mathrm{~mm}$ in total length $(X=4.6 \pm 0.50)$ extending $2-4 \mathrm{~mm}$ high $(X=2.7 \pm 0.63)$ from the surface. The thickness of the side walls $(n=11)$ ranged from 0.8 to $2.0 \mathrm{~mm}(X=1.3 \pm 0.44)$.

\subsection{Nest building and provisioning behavior}

C. flavifrons females initiated nesting activity by flying low over the nest area and landing frequently on the ground to initiate digging in multiple locations until settling on the definitive nest site. Searching females landing near the nest entrances of other females were generally driven away by the occupying female. In cases of persistent inspection of an occupied nest, both females displayed antagonistic interactions, flying over the nest and touching each other in the air.

Nest digging was initiated mainly in the morning or late afternoon and lasted 80$330 \min (X=220.5 \pm 78.5, n=12)$. On occasion, digging activity continued until around 2300 hours. Females removed soil from the tunnels by pushing it out of the entrance with the front and hind legs, using the middle leg as support while moving backwards. 
Provisioning began immediately after digging concluded for nests initiated in the morning; for nests initiated in the afternoon, females began foraging the following morning. Most foraging trips occurred in the morning $(83 \%$, $n=434$ ) with the first trip of the day beginning between 0425 and 0452 hours $(n=65)$. The return of the last trip generally took place in mid-afternoon between 1430 and 1530 hours. In summer, sunrise occurs between 0451 and 0505 hours (15-25 min after females' first morning flight) and sunset occurs at 1715-1730 hours (1-3 $\mathrm{h}$ after bees stop flying).

It takes a female approximately one and a half days (considering the circadian cycle) to complete construction and provisioning of one cell $(X=1.61 \pm 0.3, n=15$; Table I). Brood cells are filled to one third with provisions composed of a pollen mass covered by a thin liquid layer on which a cylindrical and slightly curved egg is placed. For each brood cell, the female conducted three (median) oil-collecting trips, followed by six (median) pollen-collecting trips and two (median) final oil-collecting trips for cell provisioning and closure (Figure 2b). Females use the oil from the initial oilcollecting trips to line a new cell. After lining the cell, the female collects pollen and oil for food for the larva. The oil collected on the final foraging trip is used to build the cell closure. The median number of pollen-collecting trips was significantly higher than the median number of oil-collecting trips for provisioning and closing the cell [6 vs. 2 trips (median), $Z(U)=$ 5.26, $P<0.001, d f=37$, Figure 2b]. Each female did twice as many pollen- than oil-collecting trips for lining the cell [6 vs. 3 trips (median), $Z(U)=5.05, P<0.001, d f=37]$ and significantly more oil-collecting trips for lining the cell than the median number of oil-collecting trips for provisioning and closing the cell $[Z(U)=3.53$, $P<0.001, d f=37$, Figure 2b]. Overall, continuously monitored females completed 4-11 provisioning trips per day $(X=7.0 \pm 1.6, n=434$; Figures 3 and 4 ), most of the trips to collect floral resources $(83 \%, n=434)$ occurred in the morning and trip durations were shorter at the beginning than at the end of the day (Figures 3 and 4). The first trip was very short (15-20 min) as, in general, was the last trip of the day (20$30 \mathrm{~min}$ ).

Females spent almost three times (2.7) more time on pollen-collecting trips $(75.5 \mathrm{~min}$, median) than on oil-collecting trips for lining the cell (28 min, median) $(Z=14.03, P<0.001, d f=251)$ and in oil-collecting trips for provisioning and closing the cell (29.5 min, median) $[Z(U)=6.02$, $P<0.001, d f=229$, Figure $2 \mathrm{c}]$. There was no significant difference between the median duration of oil-collecting trips for lining the cell and the median duration of oil-collecting trips for provisioning and closing the cell $[Z(U)=0.14$, $P=0.88, d f=73$, Figure $2 \mathrm{c}]$. Thus, females spent about $9.9 \mathrm{~h}$ (median) collecting the resources to construct and provision one cell $(1.4 \mathrm{~h}$ for oilcollecting trips for lining the cell, $7.6 \mathrm{~h}$ for pollen-collecting trips, and $1.0 \mathrm{~h}$ for oilcollecting trips for provisioning and closing the cell, calculated from data presented in Figure $2 b, c)$. This means that females invest in median $14 \%$ of time for oil-collecting trips to line the cell compared to $77 \%$ for pollencollecting trips and $9 \%$ for oil-collecting trips for provisioning and closing the cell.

The median duration of a nest stay after final oil-collecting trips for provisioning and closing the cell (and presumably ovipositing) was significantly higher than the median duration of a nest stay after initial oil-collecting trips (discharging oil and/or lining the cell) $[Z(U)=$ 3.98, $P<0.001, d f=61$, Figure $2 \mathrm{~d}]$, and the median duration of a nest stay after pollencollecting trips $[Z(U)=4.13, P<0.001, d f=204$, Figure $2 \mathrm{~d}]$. There was no significant difference between the median duration of a nest stay after initial oil-collecting trips (discharging oil and/or lining the cell) and after pollen-collecting trips $(Z=0.01, P=0.985, d f=240)$. At times, we observed a female digging a side tunnel $\sim 20 \mathrm{~cm}$ from the surface: pushing sand from the new tunnel to close an existing tunnel presumably containing a finished cell. We were able to observe this behavior because we excavated $\sim 10-15 \mathrm{~cm}$ down from the entrance of the nest after the bee had completed the first cell. Some females also push a little portion of 
Table I. Number of brood cells and duration time of activity (days) of nests continuously monitored since digging until closure.

\begin{tabular}{|c|c|c|c|c|}
\hline Year & Nest identification & Number of cells & Activity period & Days/cell \\
\hline \multirow[t]{8}{*}{2010} & N40 & 3 & 5 & 1.67 \\
\hline & N49 & 2 & 4 & 2.00 \\
\hline & N50 & 7 & 13 & 1.86 \\
\hline & N52 & 1 & 2 & 2.00 \\
\hline & N55 & 6 & 9 & 1.50 \\
\hline & N63 & 4 & 7 & 1.75 \\
\hline & N64 & 4 & 7 & 1.75 \\
\hline & $\mathrm{N} 71^{\mathrm{a}}$ & 6 & 11 & 1.83 \\
\hline \multirow[t]{5}{*}{2011} & $\mathrm{~N} 34^{\mathrm{a}}$ & 10 & 12 & 1.2 \\
\hline & $\mathrm{N} 42^{\mathrm{a}}$ & 6 & 8 & 1.33 \\
\hline & $\mathrm{N} 45^{\mathrm{a}}$ & 1 & 2 & 2.00 \\
\hline & N50 & 8 & 10 & 1.25 \\
\hline & N51 & 5 & 6 & 1.20 \\
\hline \multirow[t]{6}{*}{2012} & $\mathrm{~N} 113^{\mathrm{a}}$ & 12 & 19 & 1.58 \\
\hline & $\mathrm{N} 27^{\mathrm{a}}$ & 12 & 15 & 1.25 \\
\hline & Total & 87 & 130 & \\
\hline & Average & 5.8 & 8.6 & 1.61 \\
\hline & SD & 3.54 & 4.79 & 0.30 \\
\hline & Range & $1-12$ & $2-19$ & $1.20-2.0$ \\
\hline
\end{tabular}

${ }^{\mathrm{a}}$ Excavated nests in garden pots to check the number of brood cells

sand (not like when closing the nest, see below) from the surface into the nest entrance when finishing or beginning a new cell.

During the night, the female remains inside the nest, usually near the entrance with her head facing outwards, demonstrating nest-guarding behavior. Females that concluded their nests late in the afternoon were also observed remaining in nests at night and closing the tunnel entrance the following morning. When closing the nest (after completing one or more cells), the female pushes sand into the tunnel, completely obscuring the entrance using the same method of sweeping sand with her hind legs as she used when digging the nest. However, some females abandoned nests without occlusion of the main tunnel.

Three of the observed nests were reactivated after conclusion (conclusion of a nest being determined by the closure of the main tunnel with sand). One nest that had been initiated 12 days prior was reactivated 5 days after occlusion by the original founder female who resumed nesting activities for four more days. A second nest, 16 days old, was reactivated 9 days later by another female. In the third such incident, the reactivation occurred 16 days after the conclusion of the nest, but because these females were not marked, it was not possible to know their identity.

One case of usurpation of an active nest was documented, in which, during a foraging trip of the founder female, another female entered the nest and remained inside. When the founder female reentered the nest with pollen, both females exited the nest hovering near the entrance, sometimes touching each other in flight. Eventually, the founder female abandoned the nest, leaving the invader to take possession. For two consecutive days, the founder female returned to the vicinity of the nest and tried to reoccupy it without success.

Males were not observed in the aggregation although we searched for them close to nest entrances, in the garden walls, trees and neighboring roofs. 


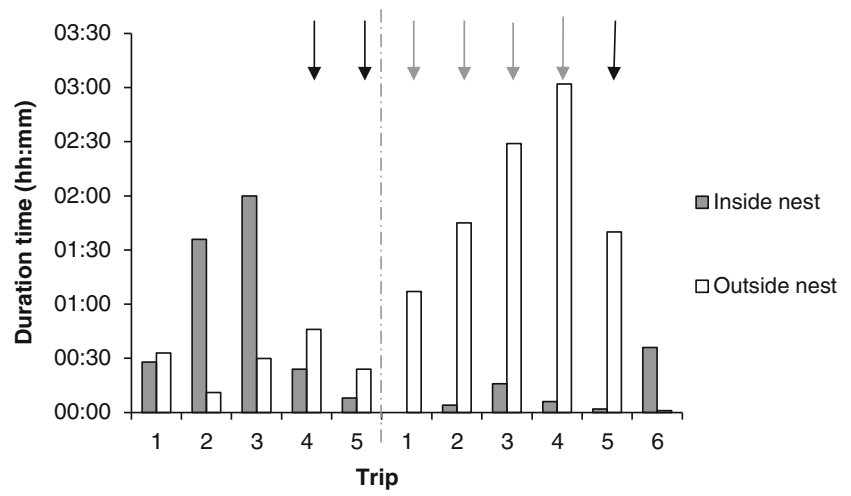

Figure 3. Duration time spent inside and outside the nest by one female. In the first day, the nest was in the digging phase (note that most of the time was spent inside the nest). On the second day, the nest was in provisioning phase. Oviposition and closure of the brood cell occurred at the end of the day. Black arrows indicate oil-collecting trips, and gray arrows indicate pollen-collecting trips. The vertical dashed line separates each day.

\subsection{Duration of activities and number of nests completed}

The total period of female activity in each nest, from digging through closure, ranged from 2 to 19 days $(X=6.9 \pm 4.2, n=141$; Figure 5; see also the summary of active period duration of continuously monitored nests in Table I); however, most of the nests (69\%) showed activity for 2-7 days. The number of cells constructed by each female ranged from 2 to 12 (Figures 3 and 4, and Table I) and was significantly correlated with her period of activity ( $r s=0.963 ; P<0.001$; this value was calculated based on the data from Table I).
Most of the marked females $(n=34)$ built only one nest, but 15 females built two nests and one female built three nests $(X=1.34$ nests/ female, $n=50$ ). Subsequent nests constructed by the same female were frequently built near the first nest.

\subsection{Nesting activity period and development of immatures}

The nesting activities of $C$. flavifrons occurred in the dry season, from September to March; however, in three consecutive years of observations, one female was recorded nesting

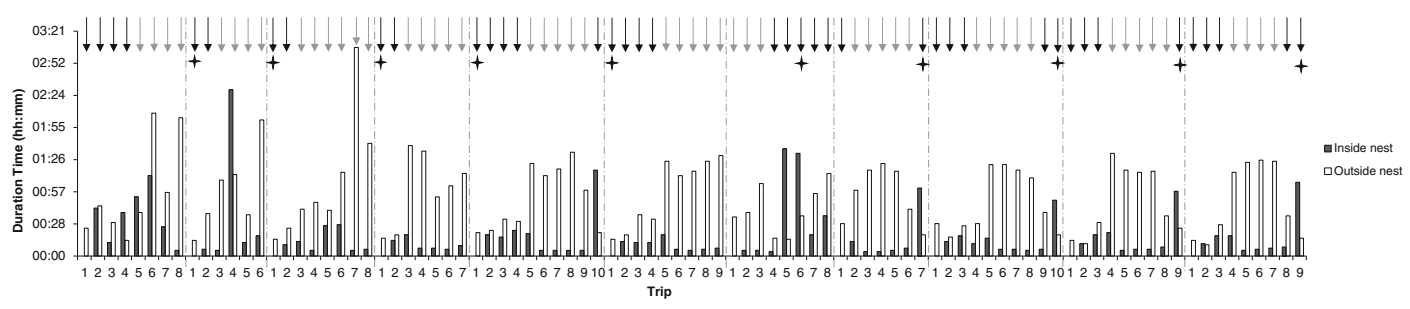

Figure 4. Time spent inside and outside the nest during cell construction, provisioning, oviposition, and cell closure by a female in the second breeding season. (The first day of activity, comprising the period of digging, is not shown in the figure). Black arrows indicate oil-collecting trips, and gray arrows indicate pollencollecting trips. Black stars indicate the time in which one cell was completed, and the vertical dashed lines separate each day. 
in May at the beginning of the rainy season (April-July).

The number of $C$. flavifrons nests founded in the first breeding season peaked twice: once in mid-November, 2010; and again in mid-January, 2011. The maximum number of active nests in the aggregation on a single day was 15 (Figure $6 a, b$ ). In the second breeding season, nest initiation was more evenly distributed over time with a marginal increase in activity in early November and late December, 2011 (Figure 6c, d).

A total of 46 brood cells were obtained from the excavation of nests in the garden pots. Most of the cells were retrieved intact. Twenty-three of the intact cells were placed in glass jars with the same utilized sandy soil to await emergence of the imagoes. Of the 23 cells, 8 imagoes emerged, 11 cells did not survive to maturity, and 4 cells were still being reared at the time this manuscript was under review. Of the emerged imagoes, there were four males and four females (a 1:1 sex ratio). Imagoes emerged in the glass jars between 59 and 81 days after nest initiation at the study site, from nests constructed in November/December and February. Since the estimated development time for all reared cells was calculated from the first day of nesting activity at the study site, these figures represent the maximum inferred development time. The survival rate for the cells placed in glass jars was $42.1 \%$ (8 out of 19 cells), with the corresponding mortality rate of $57.9 \%$ ( 11 out of 19 cells). The other 23 (of the original 46) retrieved brood cells were opened during excavation, or periodically over time. The offspring in 15 of the 23 cells were determined viable at the time of excavation; 7 had not survived. Postembryonic development to postdefecating stage (prepupa) is believed to be brief because one larva reached the last instar of predefecating stage only 11 days after the female initiated nest construction. Other cells that were opened after more than 11 days following nest initiation contained postdefecating larvae inside a cocoon. Three cells, opened 106 days after nesting began, contained live prepupae.

The total survival rate for 42 of the 46 retrieved cells (for which an outcome was determined) was $57.1 \%$. Eighteen of the 42 cells (42.9 \%) showed mortality: 6 in egg/ predefecating larval stage, 7 in prepupal stage, and 3 in pupal stage; the remaining two cells were parasitized, thus the developmental stage of these cells could not be determined. Cause of mortality for cells that did not succumb to parasites is unknown.

\subsection{Cleptoparasites}

One male and one female of Mesoplia regalis Smith emerged from the two brood cells that were parasitized of the total 42 brood cells, resulting in a total observed parasitism rate of $4.7 \%$. Both $M$. regalis imagoes emerged on the same day, 48 days after nesting initiation. Furthermore, two specimens of $M$. regalis were caught leaving the nests of $C$. flavifrons. The cleptoparasites entered the nests after a few swift, zigzag flights around the entrance and remained inside the nest for about $2 \mathrm{~min}$. Cleptoparasite visits occurred when the nesting C. flavifrons female was foraging away from the nest.

\section{DISCUSSION}

\subsection{Nest architecture and nesting activities}

The shape and dimensions of brood cells measured in this study were quite similar to $C$. flavifrons cells described from other locations and of ground-nesting Centris species in general (Vinson et al 1987; Vinson and Frankie 1988).

However, the highly variable number of brood cells per nest and the time duration of nesting activity of $C$. flavifrons observed in this study were much greater than previously recorded, indicating a degree of plasticity in nesting behavior not yet attributed to this species. The continuous monitoring of nesting activities from initiation through occlusion conducted in this study revealed that a female may remain working in the same nest for only two days or for a relatively long period (up to 19 days, mean of approximately 7 days), resulting in the construction of one to several brood cells (112 , mean of $5.8 \pm 3.54$ ). The period of activity 
previously recorded for this species was: 3 to "possible" 4 days (Vinson and Frankie 1988) or 4 to "possible" 5 days (Rêgo et al. 2006). The monitoring of nesting activities for a long period allows the detection of variability in the duration of activities in the nest. Similarly to that recorded here for C. flavifrons, Jesus and Garófalo (2000) reported a variation of 1-10 days in the activities of Centris analis females in the same nest, resulting in a range of one to four cells built per nest. Previous studies also report finding only one brood cell per C.flavifrons nest (Vinson et al. 1996, 1997; Rêgo et al. 2006), although Vinson and Frankie (1988) found one nest with two cells and Gonzalez et al. (2007) found two nests with three cells. Furthermore, nests observed by Rêgo et al. (2006) described only the main tunnel, while Vinson and Frankie (1988) observed nests with a main tunnel and lateral tunnels (branches off the main tunnel) filled with sand. Both studies reported finding only one cell per nest, which was at least $25 \mathrm{~cm}$ deep; however, the two nests found by Gonzalez et al. (2007) in Colombia consisted of a main tunnel with three lateral tunnels ending in one cell each at $\sim 12 \mathrm{~cm}$ depth. In our study, we found that the lateral tunnels terminated in one brood cell and were generally filled with sand after each cell is completed. In Habropoda miserabilis (Cresson), nesting females were not observed bringing sand to the surface after the beginning of nest provisioning. Yet, nest excavations revealed several lateral branches off the main burrow terminating in single cells similarly filled with sand after cell completion. It is presumed that the female is backfilling the tunnel to a completed cell with the sand excavated from the new lateral tunnel to the next cell, thereby minimizing energy expenditure by not bringing sand all the way up to the surface (Kim McFarland, personal communication, April 17, 2013). We also observed some $C$. flavifrons females backfilling the tunnel to a completed cell while they excavate the new lateral tunnel, confirming this behavior.

Gonzalez et al. (2007) suggest that the variation in brood cell number and nest depth exhibited by different populations of $C$. flavifrons could be associated with the morphological variation exhibited by this species or with different parasite pressure across its distri- bution, but our results show that a high variation of brood cell number can occur within the same population, thus ruling out this explanation. Alternatively, because the nest tunnels of $C$. flavifrons are relatively deep, and thus energetically expensive to dig, we suggest that this plastic nesting behavior might indicate that it is reproductively advantageous to optimize female digging effort by producing several brood cells per nest rather than just one. It is possible that any perturbation by other nesting females or parasites may cause the nesting female to close the nest and start another one. This strategy would have been effective had there been pressure to prevent parasitism in previous evolutionary time.

\subsection{Cell lining investment}

Most ground-nesting bees line their nest cells with Dufour's gland secretion (Cane 1981). It is very difficult to know the daily "cost" of Dufour's gland secretions in terms of extra foraging effort that could have been used to produce more nest cells. However, as oil bees use floral oils to line the cell, it is possible to know how much time it takes for a female to collect the oils necessary for lining the nest cell as well as the time it takes to provision the cells with pollen and oil. From our data, the median time spent in foraging trips for oil (for lining), for pollen, and for oil again (for provisions and lining) was $1.4,7.6$, and $1.0 \mathrm{~h}$, respectively (calculated from data presented in Figure 2b, c). Thus, $C$. flavifrons females used $14 \%$ (median) of foraging time to line the cell. That means that a female could produce one more cell for every six nest cells provisioned if the time invested to line the cells was invested in provisioning. Thus, it is expected that a larva in a lined nest cell is at least $14 \%$ less likely to die (presumably from mold) than one in an unlined nest cell. From the excellent study by Schäffler and Dötterl (2011), we did similar calculations that showed that females of Macropis fulvipes (Fabricius) use $26.3 \%$ of the total foraging time (median number of oil trips $\times$ median duration of oil trips) for lining one cell. These results suggest that oil bees invest 


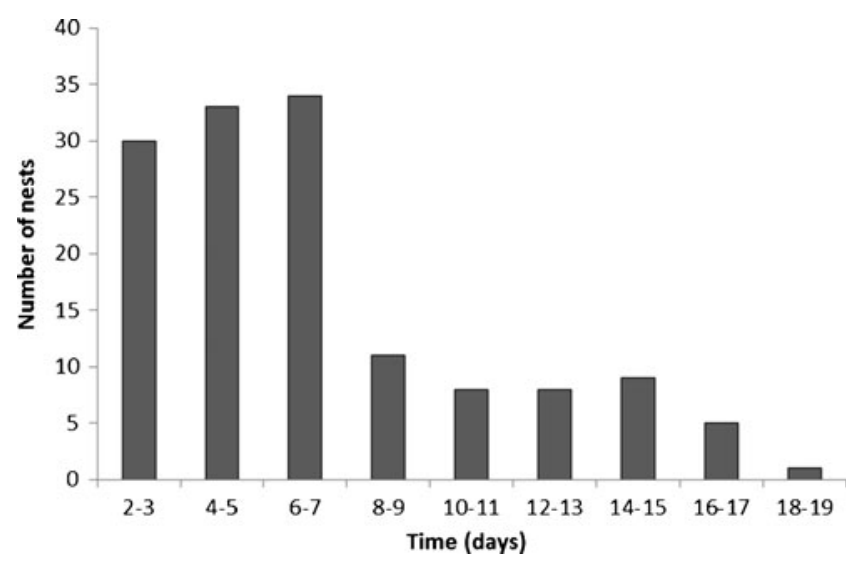

Figure 5. Frequency of $C$. flavifrons nests active over the duration (days) from digging until closure $(n=141)$.

a minor part of the overall foraging and provisioning effort, with no cost in excreted lipids, unlike most ground-nesting bees. Further comparisons with other ground-nesting bees are necessary to confirm this assumption.

Although the number of oil collecting trips to construct the nest cell lining is somewhat similar in several studied oil bees, differences exist in the time invested in one oil collecting trip (Camillo et al. 1993; Jesus and Garófalo 2000; Aguiar and Gaglianone 2003; Aguiar and Garófalo 2004; Schäffler and Dötterl 2011). Additional studies are necessary to compare the behavior of oil bees regarding the effort to line and provision each cell.

\subsection{Seasonality and number of generations}

Our observation of concentrated nesting activity in the warm/dry season (SeptemberFebruary) is in accord with previous records of reproductive activity in other areas of the Neotropics for this species (Vinson and Frankie 1988; Rêgo et al. 2006). Other species of non-eusocial bees nesting in this region of the northeastern Brazil coastline show similar greater nesting abundance in this season (Aguiar and Martins 2002, 2003; Martins and Souza 2005; Farias et al. 2008). Flowering occurs mainly during the dry period and at the start of the rainy season (Lima et al. 2008) in this region, and this is likely the ultimate causation of seasonality of some solitary bee species in this area.

The duration of the breeding season (about 6 months) combined with the brood development period (about 60-80 days) of the species suggests the production of two to three generations per year. The development of the immatures to prepupal stage is relatively fast. The almost complete cessation of activity of females between March and August (rainy season) and the resumption of nesting activities in September observed over consecutive years allow us to assume that the latest generation produced in the reproductive season ( February) has a development time considerably longer than the generations produced at the beginning of the breeding season. The three cells containing live prepupae more than 3.5 months old after the nesting season had ended, support this claim. Furthermore, one adult male emerged after the preparation of this manuscript (one of the four cells still being reared at the time this manuscript was under review) in a minimum of 207 days ( $\sim 7$ months) after cell construction, showing that a long development time and diapause may occur in C. flavifrons. Differences in the development time among generations were reported in other 

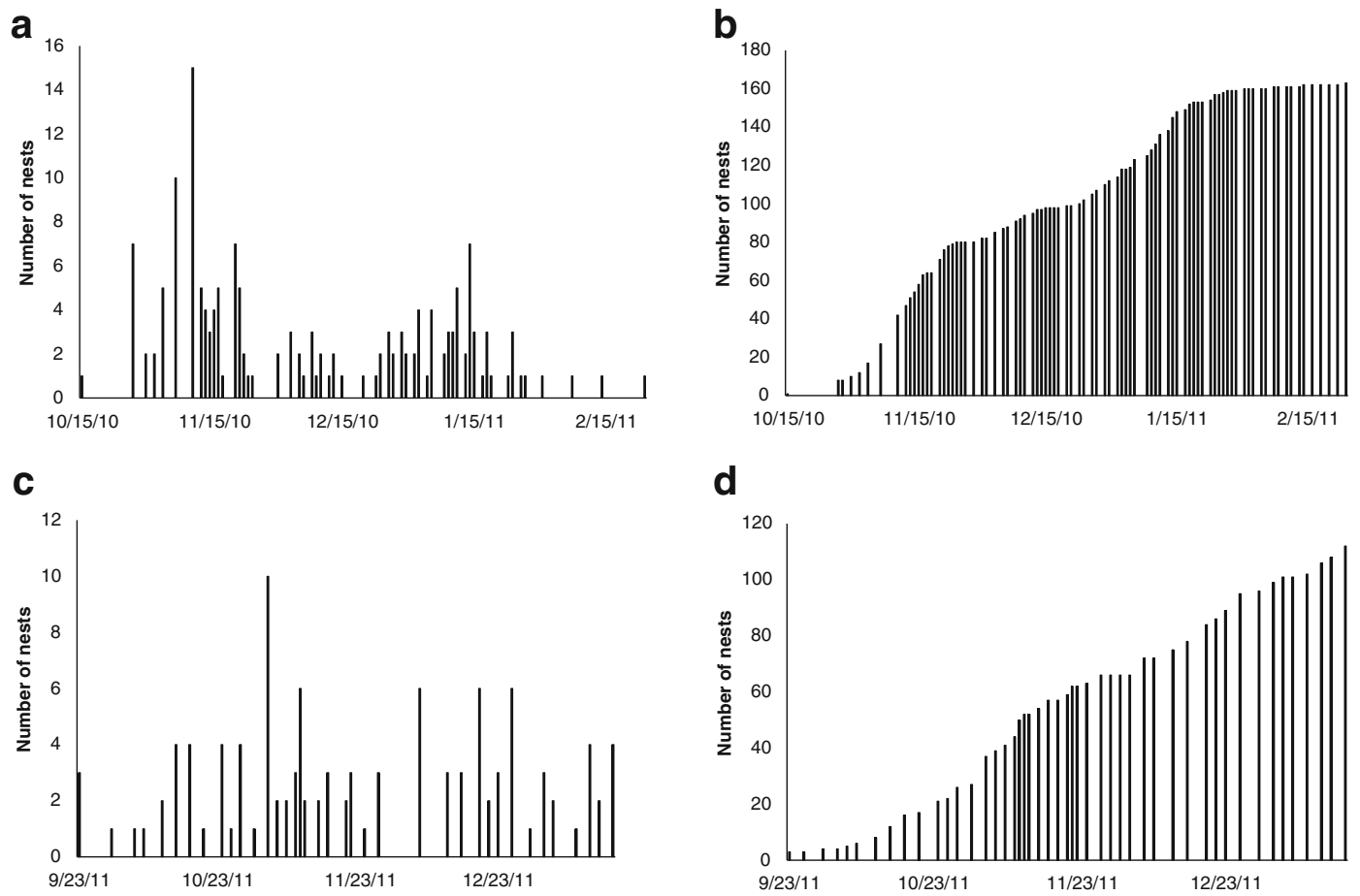

Figure 6. a Number of established nests per day in the study area during the first breeding season of $C$. flavifrons. b Cumulative number of established nests in the study area during the first breeding season. c Number of established nests per day in the study area during the second breeding season. $\mathbf{d}$ Cumulative number of established nests in the study area during the second breeding season.

Centris species. In a population of $C$. analis in southeastern Brazil, Jesus and Garófalo (2000) found significant differences in the development time, for both sexes, between two nesting periods (from early-November to late-February, mid of the wet/hot season, and March, late wet/hot season). In a population of $C$. tarsata in northeastern Brazil four generations per year were reported; three generations showed fast development (emergence after 5-6 weeks) and a single generation showed delayed development (individuals from two nests established in late May emerged 139 days after the nests were collected) (Aguiar and Garófalo 2004). Additionally, in another population living prepupae were found 7 months after the nests had been established. The observed late nesting activity (May-June) of $C$. flavifrons over four consecutive years by isolated females in the study site suggests that at least some of the offspring from nests established towards the end of the nesting season (February) may emerge in early fall (beginning of rainy season), but most of the offspring probably remain as prepupa in the brood cells until the following spring. These findings are similar to that reported in a population of $C$. tarsata in Brazil, where the offspring of most nests established in November/ December quickly emerged (5-6 weeks), while the development time of the immatures in some nests established within the same period was much longer, suggesting occurrence of diapause as prepupae.

\subsection{Nesting density, philopatry and parasitism}

The females of $C$. flavifrons established aggregated nests in flat ground, with preferential use and higher density of nests in areas without vegetation than in areas covered with grass as observed by 
Rêgo et al. (2006). In the present study, the nests were further aggregated within the aggregation. The behavior of nesting in dense aggregations has also been reported for other species of the genus Centris, such as $C$. aenea (Michener and Lange 1958; Aguiar and Gaglianone 2003), Centris caesalpiniae (Rozen and Buchmann 1990) and Centris tamarugalis (Chiappa and Toro 1994). Conversely, Vinson and Frankie (1988) observed widely scattered $C$. flavifrons nests mostly located in the side-walls of burrows excavated by a large iguanid lizard. This behavior also reinforces the plasticity in the nesting behavior of this species.

The aggregation of nests within the study area in conjunction with the repeated use of the same nesting area for at least four consecutive years suggests that $C$. flavifrons exhibits philopatry. Although a few marked females that had emerged in the cages from nests during this study were not observed again at the nest area, C. flavifrons nests were observed in the same area 10 years ago and have been studied here over the past four years. Some nests were detected in neighboring gardens $100 \mathrm{~m}$ away, suggesting that the nesting area is larger than the studied area. It is possible that the marked females that constructed only one nest $(68 \%)$ nested within the larger nesting area outside of the study site; thus, the degree of philopatric behavior may be greater than detected. Further studies, including genetic analysis methods currently being developed, will be helpful to clarify this aspect of nesting behavior.

We were surprised not to observe mating at the nest aggregation. The mating sites of $C$. flavifrons were not identified nor were any males collected in the study area, except for two males that emerged in cages placed over recently concluded nests, and the four males that emerged from the monitored cells reared in the glass jars. The principle investigator of this study (CF Martins) several years ago observed a cluster of males intercepting females during flight. The males were on a roof outside of a residence approximately $5 \mathrm{~km}$ distant from the study area about $3 \mathrm{~m}$ above an aggregation of nests. Vinson et al. (1996) reported that males of C. flavifrons mark and defend territories in Byrsonima crassifolia trees, regardless of whether or not they are in flower. Based on the high number of hours of observation, it is plausible to state that mating does not occur in the vicinity of nests similar to what has been described for other ground-nesting species of the same genus, e.g., $C$. pallida (Alcock et al. 1976) and C. tamarugalis (Chiappa and Toro 1994).

The females of $C$. flavifrons exhibited nest defense behavior by remaining close to the entrance of the nest at night and contacting the bodies of other females that come near the nest entrance during flight. We recorded several nonfounder females entering nests belonging to other females and successful nest usurpation was documented in one case. Vinson and Frankie (1988) described a similar case of nest usurpation during the absence of the founder female in this species. Nest usurpation by cospecific females was previously reported for at least two cavity-nesting Centris species: $C$. analis (Jesus and Garófalo 2000) and C. bicornuta (Vinson and Frankie 2000). For bee species in which the tunnel digging effort is energetically expensive, such as $C$. flavifrons who spends approximately 1 day (or 2 days, see Vinson and Frankie 1988) constructing the tunnels, the strategy of usurping nests with completed tunnels would be particularly advantageous, since it reduces the time and energy investment of the usurper female to establish their own nests.

The overall mortality rate reported here $(42.8 \%$, $n=42$ ) is probably underestimated because the calculation included larvae that were determined alive at the time the cell was examined, but might have died at a later time if left in the nest. The higher mortality rate of imagoes emerged from cells kept in glass jars $(57.9 \%, n=19)$ might have been influenced by the manipulation of the cells; a white fungus frequently appeared outside the walls of the cells, but not on the cells kept in sterilized soil. Thus, the actual mortality rate is probably somewhere between these two estimates.

For the first time, C. flavifrons is confirmed to be a host (sensu Rocha-Filho et al. 2009) for the cleptoparasite $M$. regalis. However, it is noteworthy that the parasitism rate in the study area was very low ( $4.7 \%$ in a total of 42 cells). Rozen et al. (2011) observed an extremely high rate of parasitism by Mesoplia sapphirina on its host, 
C. flavofasciata, of 90 and $30 \%$ (based on a sample of 10 in 2010 and 36 cells in 2011 at the same site, respectively), and Vinson et al. (1987) reported a parasitism rate of $59 \%$ (22 cells sampled) for the same two species. It is notable that Vinson and Frankie (1988) reported a heavy parasite pressure from Mesoplia sp. on $C$. flavifrons nests, and regarded parasite pressure as the main reason for the construction of scattered nests containing blind side tunnels. These authors frequently observed Mesoplia sp. entering the nests of $C$. flavifrons and digging in the tunnels. On the other hand, Rozen et al. (2011) reported a high variation and a decrease in the parasitism rate in two consecutive years. However, it should be expected an increase of parasitism over time, or at least a higher rate, in the urban aggregation of $C$. flavifrons studied. Nevertheless, despite the occurrence of $M$. regalis in the nesting area, there was a low pressure of parasites, and the frequency of these cleptoparasites does not seem to be a limiting factor for the population of $C$. flavifrons.

\subsection{Concluding remarks}

Fragmentation and habitat loss affect pollinator communities and may be responsible for the decline of many bee species (Müller et al. 2006; Andrieu et al 2009). Because urban areas are an extreme case of habitat fragmentation it is important to know whether pollinators can adapt their foraging behavior in these areas (Andrieu et al 2009). Moreover, the knowledge about nesting requirements is crucial to conserve populations of bees. We studied the bionomics of a solitary, ground-nesting bee species in an urban area. It is likely that the results regarding the architecture of nests, sequence of construction and provisioning of brood cells is similar to that practiced in natural environments; however, the duration of collection trips may differ depending on the availability of floral resources. The presence of a forest fragment relatively close to the study area may have minimized the duration of collection trips in this study from what might be observed in more developed urban environments. In addition, in 3 years, eight nests were constructed in garden pots suggesting the potential for enhancing nesting resources with manmade structures as a method for future population management of solitary, ground-nesting bees in urban areas. However, long term studies are necessary to understand the population dynamics of the plastic nesting behavior of $C$. flavifrons and its parasite.

\section{ACKNOWLEDGMENTS}

We thank Carolina Liberal, Jerônimo Kahn VillasBôas, Liedson Tavares Carneiro, Renata Marinho Cruz, Rita P. Lima and Vaneide Lopes do Nascimento, for the help in field work; Jim Cane and Kim McFarland for reading the manuscript and constructive criticism; and CAPES and the Brazilian Research Council (CNPq) for their financial support.

Plasticité du comportement de nidification de Centris (Centris) flavifrons (Hymenoptera: Apidae: Centridini) en zone urbaine

Ecologie / nid souterrain / abeille solitaire / abeille récolteuse d'huile / Mesoplia regalis / Brésil

Flexibilitát im Nistverhalten von Centris (Centris) flavifrons (Hymenoptera: Apidae: Centridini) in einer städtischen Umgebung

Nistökologie / Bodennester / solitäre Bienen / ölsammelnde Bienen / Mesoplia regalis

\section{REFERENCES}

Aguiar, A.J.C., Martins, C.F. (2002) Abelhas e vespas solitárias em ninhos-armadilha na Reserva Biológica Guaribas (Mamanguape, Paraíba, Brasil). Rev. Bras. Zool. 19(Supl), 101-116

Aguiar, A.J.C., Martins, C.F. (2003) The bee diversity of the Tabuleiro vegetation in the Guaribas Biological Reserve (Mamanguape, Paraíba, Brazil), in: G.A.R. Melo and Alves-dos-Santos, I. (Eds.), Apoidea Neotropica: Homenagem aos 90 anos de Jesus Santiago Moure, pp. 209-216. Criciúma, Editora UNESC

Aguiar, C.M.L., Gaglianone, M.C. (2003) Nesting biology of Centris (Centris) aenea Lepeletier (Hymenoptera, Apidae, Centridini). Rev. Bras. Zool. 20(4), 601-606 
Aguiar, C.M.L., Garófalo, C.A. (2004) Nesting biology of Centris (Hemisiella) tarsata (Hymenoptera, Apidae, Centridini). Rev. Bras. Zool. 21, $477-486$

Aguiar, C.M.L., Garófalo, C.A., Almeida, G.F. (2006) Biologia da nidificação de Centris (Hemisiella) trigonoides Lepeletier (Hymenoptera, Apidae, Centridini). Rev. Bras. Zool. 23, 323-330

Albuquerque, P.M.C., Rêgo, M.M.C. (1989) Fenologia das abelhas visitantes de murici (Byrsonima crassifolia, Malpighiaceae). Bol. Mus. Para. Emílio Goeldi, sér. Zool. 5(2), 163-178

Alcock, J., Jones, C.E., Buchmann, S.L. (1976) Location before emergence of the female bee, Centris pallida, by its male (Hymenoptera: Anthophoridae). J. Zool. 197, 189-199

Andrieu, E., Dornier, A., Rouifed, S., Schatz, B., Cheptou, P.O. (2009) The town Crepis and the country Crepis: how does fragmentation affect a plant-pollinator interaction? Acta Oecol. 35, 1-7

Bezerra, E.S., Lopes, A.V., Machado, I.C. (2009) Biologia reprodutiva de Byrsonima gardnerana A. Juss. (Malpighiaceae) e interações com abelhas Centris (Centridini) no Nordeste do Brasil. Rev. Bras. Bot. 32(1), 95-108

BioEstat (2007) Version 5.3. http://www.mamiraua.org.br/ downloads/programas

Camillo, E., Garófalo, C.A., Serrano, J.C. (1993) Hábitos de nidificação de Melitoma segmentaria, Centris collaris, Centris fuscata e Paratetrapedia gigantea (Hymenoptera, Anthophoridae). Rev. Bras. Entomol. 37, 145-156

Cane, J.H. (1981) Dufour's gland secretion in the cell linings of bees (Hymenoptera: Apoidea). J. Chem. Ecol. 7, 403-410

Cane, J.H., Gerdin, S., Wife, G. (1983) Mandibular gland secretions of solitary bees (Hymenoptera, Apoidea)-potential for nest cell disinfection. J. Kans. Entomol. Soc. 56, 199-204

Cane, J.H., Neff, J.L. (2011) Predicted fates of groundnesting bees in soil heated by wildfire: thermal tolerances of life stages and a survey of nesting depths. Biol. Conserv. 144, 2631-2636

Chiappa, E., Toro, H. (1994) Comportamiento reproductivo de Centris mixta tamarugalis (Hymenoptera: Anthophoridae). II Parte: Nidificacion y estados inmaduros. Rev. Chil. Entomol. 21, 99-115

Dórea, M.C., Aguiar, C.M.L., Figueroa, L.E.R., Lima, L.C.L., Santos, F.A.R. (2010a) Residual pollen in nests of Centris analis (Hymenoptera, Apidae, Centridini) in an area of caatinga vegetation from Brazil. Oecologia Australis 14, 232-237

Dórea, M.C., Aguiar, C.M.L., Figueroa, L.E.R., Lima, L.C.L., Santos, F.A.R. (2010b) Pollen residues in nests of Centris tarsata Smith (Hymenoptera, Apidae, Centridini) in a tropical semiarid area in NE Brazil. Apidologie 41, 557-567
Elliott, J.M. (1977) Some methods for the statistical analysis of samples of benthic invertebrates. Freshw. Biol. Assoc. 25, 2nd edition

Farias, R.C.A.P., Madeira-da-Silva, M.C., PereiraPeixoto, M.H., Martins, C.F. (2008) Composição e sazonalidade de espécies de Euglossina (Hymenoptera: Apidae) em Mata e Duna na área de proteção ambiental da Barra do Rio Mamanguape, Rio Tinto, PB. Neotrop. Entomol. 37(3), 253-258

Freitas, B.M., Alves, J.E., Brandão, G.F., Araújo, Z.B. (1999) Pollination requirements of West Indian cherry (Malpighia emarginata) and its putative pollinators, Centris bees, in NE Brazil. J. Agric. Sci. 133, 303-311

Frankie, G.W., Vinson, S.B., Williams, H. (1989) Ecology and evolutionary sorting of 12 sympatric species of Centris bees in Costa Rican dry forest. In: Bock, J.H., Linhart, Y.B. (eds.) The Evolutionary Ecology of Plants. Westview Press, Boulder, Colorado

Gaglianone, M.C., Rocha, H.H.S., Benevides, C.R., Junqueira, C.N., Augusto, S.C. (2010) Importância de Centridini (Apidae) na polinização de plantas de interesse agrícola: o maracujá-doce (Passiflora alata Curtis) como estudo de caso na região sudeste do Brasil. Oecologia Australis 14(1), 152-164

Gonzalez, V.H., Ospina, M., Palacios, E., Trujillo, E. (2007) Nesting habitats and rates of cell parasitism in some bee species of the genera Ancyloscelis, Centris and Euglossa (Hymenoptera, Apidae) from Colombia. Bol. Mus. Entomol. Univ. del Valle 8(2), 23-29

Gottsberger, G., Camargo, J.M.F., Sillberbauer-Gottsberger, I. (1988) A bee pollinated tropical community: the beach dune vegetation of Ilha de São Luis, Maranhão, Brazil. Bot. Jahrb. Syst. 109, 469-500

Jesus, B.M.V., Garófalo, C.A. (2000) Nesting behaviour of Centris (Heterocentris) analis (Fabricius) in southeastern Brazil (Hymenoptera, Apidae, Centridini). Apidologie 31, 503-515

Laroca, S., Reynaud dos Santos, D.T., Schwartz Filho, D.L. (1993) Observations on the nesting biology of three Brazilian centridine bees: Melanocentris dorsata (Lepeletier 1841), Ptilotopus sponsa (Smith 1854) and Epicharitides obscura (Friese 1899) (Hymenoptera: Anthophoridae). Trop. Zool. 6, 153-163

Lima, A.L.A., RODAL, M.J.N., LINS-e-SILVA, A.C.B. (2008) Phenological characterization of an arboreal atlantic forest assemblage in Pernambuco, Brazil. Bioremediation Biodivers. Bioavailab. 2, 68-75

Lima, P.J., Heckendorff, W.D. (1985) Climatologia. In Atlas Geográfico do Estado da Paraíba. Universidade Federal de Paraíba, João Pessoa. p. 34-43

Martins, C.F., Souza, A.K.P. (2005) Estratificação vertical de abelhas Euglossina (Hymenoptera: Apidae) em uma área de Mata Atlântica, Paraíba, Brasil. Rev. Bras. Zool. 22(4), 913-918

Michener, C.D. (2007) Bees of the World, 2nd edn. Johns Hopkins University Press, Baltimore 
Michener, C.D., Lange, R.B. (1958) Observations on the ethology of Neotropical Anthophorine bees (Hymenoptera: Apoidea). Univ. Kans. Sci. Bull. 39, 69-96

Müller, A., Diener, S., Schnyder, S., Stutz, K., Sedivy, C., Dorn, S. (2006) Quantitative pollen requirements of solitary bees: implications for bee conservation and the evolution of bee-flower relationships. Biol. Conserv. 130, 604-615

Oliveira, R., Schlindwein, C. (2009) Searching for a manageable pollinator for Acerola orchards: the solitary oil-collecting bee Centris analis (Hymenoptera: Apidae: Centridini). J. Econ. Entomol. 192, 265-273

Peakall, R., Schiestl, F.P. (2004) A mark-recapture study of male Colletes cunicularius bees: implications for pollination by sexual deception. Behav. Ecol. Sociobiol. 56, 579-584

Pina, W.C., Aguiar, C.M.L. (2011) Trap-nesting bees (Hymenoptera: Apidae) in orchards of Acerola (Malpighia emarginata) in a semiarid region of Brazil. Sociobiology. 58(2), 379-392

Quiroz-Garcia, D.L., Martinez-Hernandez, E., PalaciosChavez, R., Galindo-Miranda, N.E. (2001) Nest provisions and pollen foraging in three species of solitary bees (Hymenoptera: Apidae) from Jalisco, México. J. Kans. Entomol. Soc. 74, 61-69

Rabelo, L.S., Vilhena, A.M.G.F., Bastos, E.M.A.F., Augusto, S.C. (2012) Larval food sources of Centris (Heterocentris) analis (Fabricius, 1804) (Hymenoptera: Apidae), an oil-collecting bee. J. Nat. Hist. 46, 1129-1140

Rêgo, M.C.M., Albuquerque, P.M.C., Ramos, M.C., Carreira, L.M. (2006) Aspectos da biologia de nidificação de Centris flavifrons (Friese) (Hymenoptera: Apidae, Centridini), um dos principais polinizadores do murici (Byrsonima crassifolia L. Kunth, Malpighiaceae), no Maranhão. Neotrop. Entomol. 35(5), 579-587

Rocha-Filho, L.C., Morato, E.F., Melo, G.A.R. (2009) New host records of Aglaomelissa duckei and a compilation of host associations of Ericrocidini bees (Hymenoptera: Apidae). Zoologia 26(2), 299-304

Roubik, D.W., Villanueva-Gutiérrez, R. (2009) Invasive Africanized honey bee impact on native solitary bees: a pollen resource and trap nest analysis. Biol. J. Linn. Soc. 98, 152-160
Rozen, J.G., Buchmann, S.L. (1990) Nesting biology and immature stages of bees Centris caesalpiniae, C. pallida, and the cleptoparasite Ericrocis lata (Hymenoptera: Apoidea, Anthophoridae). Am. Mus. Novit. 2985, 1-30

Rozen Jr., J.G., Vinson, S.B., Coville, R., Frankie, G. (2011) Biology of the cleptoparasitic bee Mesoplia sapphirina (Ericrocidini) and its host Centris flavofasciata (Centridini) (Apidae: Apinae). Am. Mus. Novit. 3723, 1-36

Schäffler, I., Dötterl, S. (2011) A day in the life of an oil bee: phenology, nesting, and foraging behavior. Apidologie 42, 409-424

Teixeira, L.A.G., Machado, I.C. (2000) Sistema de polinização e reprodução de Byrsonima sericea DC (Malpighiaceae). Acta Bot. Bras. 14(3), 347-357

Thiele, R. (2002) Abejas polinizadoras de árboles del Nordeste de Costa Rica: Ecología, protección e importancia silvicultural de las Centridini. Deutsche Gesellschaft für Technische Zusammenarbeit, 57 pp

Vilhena, A.M.G.F., Rabelo, L.S., Bastos, E.M., Augusto, S.C. (2012) Acerola pollinators in the savanna of Central Brazil: temporal variations in oil-collecting bee richness and a mutualistic network. Apidologie 43, 51-62

Vinson, S.B., Frankie, G.W. (1988) A comparative study of the ground nests of Centris flavifrons and Centris aethiocesta (Hymenoptera: Anthophoridae). Entomol. Exp. Appl. 49, 181-187

Vinson, S.B., Frankie, G.W. (2000) Nest selection, usurpation, and a function for the nest entrance plug of Centris bicornuta (Hymenoptera: Apidae). Ann. Entomol. Soc. Am. 93(2), 254-260

Vinson, S.B., Frankie, G.W., Coville, R.E. (1987) Nesting habits of Centris flavofasciata Friese (Hymenoptera: Apoidea: Anthophoridae) in Costa Rica. J. Kans. Entomol. Soc. 60, 249-263

Vinson, S.B., Frankie, G.W., Williams, H.J. (1996) Chemical ecology of the genus Centris (Hymenoptera: Apidae). Fla. Entomol. 79, 109-129

Vinson, S.B., William, H.J., Frankie, G.W., Shrum, G. (1997) Floral lipid chemistry of Byrsonima crasssifolia (Malpighiaceae) and a use of floral lipids by Centris bees (Hymenoptera: Apidae). Biotropica 29, 76-83 